\title{
A Brief Research on EU-China Comprehensive Agreement on Investment
}

\author{
Yuqi Fu 1, a, $\dagger, *$, Shuyuan Yang $2, b, \dagger,{ }^{*}$, Jiayang Zhang $3, \mathrm{c}, \dagger, *$ \\ ${ }^{1}$ Law School, Ocean University of China, Qingdao, Shan Dong Province, China \\ ${ }^{2}$ Management School, Guangzhou University, Guangzhou, Guangdong Province, China \\ ${ }^{3}$ High School, Haileybury International School Tianjin, Tianjin, Tianjin, China \\ *Corresponding author.Email: ${ }^{*} 18150022012 @$ stu.ouc.edu.cn, ${ }^{b} 3209469560 @ q q . c o m,{ }^{c}$ lleeeoooo@126.com \\ †These authors contributed equally.
}

\begin{abstract}
The purpose that we write this paper is to talk about the benefits and influences of the China-EU Comprehensive Investment Agreement and help prompt its signing. As all the world sees, the agreement's progress has stagnated because the EU has some conflicts of concepts with China. However, we hope the two sides can put the facts in perspective and reach an early agreement. Also, to prove that our view, that signing the China-EU Comprehensive Investment Agreement is beneficial not only for the EU and China but also for all the world, is correct. We read many articles and found that most scholars held the same points as ours. What's more, we hope that this article can make Europe aware of the importance of cooperating with China. We believe that the misunderstanding between China and Europe can be overcome, and the EU will put down its prejudice and restart the process of signing the agreement. If so, it will be a win-win situation for both sides. For China, the development of foreign trade can promote economic development. For the EU, it will have similar influences. In addition, economy and politics are closely linked, and economic growth can drive political changes. After signing the China-EU Comprehensive Investment Agreement, it can be believed that China and the EU will have greater influences and higher voices on significant events. In conclusion, we consider the China-EU Comprehensive Investment Agreement as a good thing.
\end{abstract}

Keywords: The China-EU Comprehensive Investment Agreement, economic recovery, win-win situation.

\section{LITERATURE REVIEW}

Ronald.C.Brown expressed his views in his article published on 23/12/2019 in Washington International Law Journal. He said that 'It is time for European Union and Chinese leaders to build on the existing EU-China 2020 Strategic Agenda for Cooperation, quickly conclude on-going negotiations on their EU-China Bilateral Investment Treaty, and begin substantive negotiations on an EU-China Free Trade Agreement' [1]. What's more, on 15/03/2021, China's Foreign Trade published the article, written by Xinwei Liu, which said that with the China-European Comprehensive Investment Agreement, the potential of China-EU trade would be greatly released [2]. Also, in 21st Century Business Herald, 29/03/2021, the newspaper described their points that China-European Comprehensive Investment Agreement is in the interests of both sides and beneficial to the world.

We agree with the points above, especially the first one, specific to the current situation. During the epidemic period, the global economy suffered a major blow, and China and Europe were not spared. Therefore, they need a platform to recover and develop their economy. It is very urgent to sign this agreement. Although the European Parliament has called a halt to the deliberation of the China-European Comprehensive Investment Agreement. In the long run, the agreement is that EU investors will achieve better access to a fastgrowing 1.4 billion consumer market and compete on a better level playing field.

There is increasing common interest and cooperation between the European Union and China. European Council President, Donald Tusk, has called for the World Trade Organization reform, including new rules 
on industrial subsidies and intellectual property rights, as Europe tries to form a common front with China against Washington's trade tariffs. It is time for the European Union and China to build on the existing EUChina 2020 Strategic Agenda for Cooperation, quickly conclude on-going negotiations on their EU-China Bilateral Investment Treaty ("BIT"), and initiate and expedite formal substantive negotiations on an EUChina FTA. China is now the European Union's secondbiggest trading partner behind the United States, and the European Union is China's biggest trading partner [3]. The resulting FTA could enhance trade opportunities and contribute to China's employment opportunities and rising labor standards.

\section{BASIC BACKGROUND AND STATUS OF CORPORATION}

\subsection{For $E U$}

We choose 2016 as an important time point because, on June 23, 2016, the UK officially announced its departure from the EU; on January 31, 2020, the UK officially left the EU.

Economically, although the total impact of this event on the European Union is limited, it is undeniable that the UK is one of the core countries of the European economy. The loss of the UK has a big impact on the EU economy. Before the epidemic, the economic growth of the European Union in 2016-2019 has been slower than the $2.4 \%$ growth rate before the European debt crisis, indicating that the economic growth in this process lacks momentum. Moreover, what the EU has lost is a large country and an important political partner. Here we would like to introduce to you the concept of "European integration". European integration refers to the idea of "European Union" and "European unity" put forward by European countries to achieve peace, eliminate war, and develop the economy. Also, measures will be taken to achieve these goals. Brexit, which means British exit or Britain exiting from the EU (We will use this word to express it in the following), has hindered European integration and made the relationship between the unstable member states face more severe challenges. Even more member states may consider whether to exit from the EU.

And COVID-19 has a huge blow to the EU, especially the economy. Specifically, consumer demand has plummeted, industrial development has suffered a serious setback, and trade and tourism, these aspects that we mention, have suffered a serious impact. Take the museum industry in Europe as an example. According to the statistics of the French Council of professional galleries, the total loss of 279 member galleries has exceeded 148 million euros in the first round of the European epidemic, that is, from March to June 2020. Large museums, such as Rijksmuseum and
Stedelijk Museum Amsterdam, are losing 100000 to 600000 euros a week due to the epidemic. Private small regional museums have been hit more seriously by the epidemic, with less than 40000 visitors per year. Moreover, many such cultural institutions are not eligible for the 300 million euro assistance provided by the Dutch government to the cultural sector. To this end, $25 \%$ of museums in the Netherlands are expected to be permanently closed due to the epidemic.

Therefore, at this time, the EU needs a strong economic partner to stimulate economic recovery and enhance the confidence of Member States to maintain the process of European integration.

\subsection{For China}

Economically, Before the epidemic, China's domestic and foreign economy had been in good progress. In foreign trade, it is worth mentioning that China has been adhering to the belt and road strategy. The belt and road is a cooperation initiative put forward by China, which aims to develop economic cooperation with relevant countries in Asia, Africa, and Europe and build a community of interests with the help of the existing platform. Similarly, China's economy is facing severe challenges because of COVID-19[10]. Therefore, China needs a foreign trade platform to resume foreign trade and "the belt and road" strategy so that the domestic and foreign economies can recover. On the other hand, the attitude of Britain and the United States towards China is becoming harsher and harsher. Therefore, China needs a reliable partner. The closer China's interests are with the rest of the world, the more difficult it becomes to attack China.

\section{PREDICTIONS IF CHINA-EU COMPREHENSIVE AGREEMENT ON INVESTMENT WON'T COME OUT}

For the EU, it will be a loss both economically and politically. Firstly, and most importantly, China's EU trade has not been developed, and the European economy still has no driving force for development. Secondly, the current relationship between the EU and the United States is very delicate. Without this agreement, the EU will lose its important chips and be at a disadvantage. In particular, the epidemic has not been completely controlled. Therefore, if the EU is still in a difficult situation, it will not get a satisfactory result from the US EU vaccine negotiations [4]. Thirdly, brexit is still in the transitional period. If the agreement is not finally signed, the EU will lose its dominant position in the negotiations with the UK.

For China, things will be better. Suppose the "one belt, one road" strategy cannot be further developed and will not be conducive to the resumption of foreign trade. In that case, some export-oriented enterprises will 
become more difficult. But for the overall Chinese economy, the Chinese government can implement many economic policies to support these enterprises. However, from a political point of view, the current political situation is unfavorable to China. Both the United States and the United Kingdom have adopted sanctions against China. If we cannot have a partner with a high voice like the European Union and have no interest in binding with such a large economy, China's situation will be even more difficult.

\section{NEW REGULATIONS ABOUT IP}

The China-EU comprehensive investment agreement predicts that it won't come out. One reason is that the current trading atmosphere is not fair and beneficial for both China and Europe. When the enterprises undergo the China-Eu comprehensive agreement, there are many international trade problems such as the imitation of logo or products from other multinational enterprises. This kind of problem is about IP, which means intellectual property. Because of the special property of the China-Eu comprehensive agreement, international trading will face lots of problems in the process of practicing. One significant aspect is intellectual property. It concludes the logo, technique, advertisement, etc.

The range of intellectual property is various. Intellectual property refers to "the exclusive rights legally enjoyed by the right holder to the achievements created by intellectual labor and the marks and reputations in business activities", which are generally valid only for a limited period. The range of the IP is various, from the company's logo to the technique used to manufacture the product. Everything unique is the IP for the enterprise. For example, the big yellow "M" from Mcdonald's is one of the most famous IPs in the whole world, and the joker from Mcdonald's is their intellectual property, too. The positive effect of the logo "M" is that when people see the big yellow M, they will think of the juicy burger from Mcdonald's. And their brain will produce specific chemicals to force them to go to the Mcdonald's with friends or family members to taste the flavor of the burger and coke.

Go back to the IP's relationship with the China-EU comprehensive agreement. To stimulate the trade environment of both China and Europe, more and more local companies will have to compete with multinational enterprises. To win from the intense competition, every enterprise uses any method to gain more market share and profit [5]. The benefit of IP, like a famous logo, can build a positive impression to both customers and employees, which means the enterprise can attract more resources to strengthen the competitive power in the world. In addition, application for a patent is not eager to develop the patented technology into products on the market, but as a technical reserve, until the previous generation of products fully develop the market role and then launch the second generation of products. Competitors acquire intellectual property cheaply through improper means such as imitation, copying, reverse engineering, and corporate espionage to produce new products to compete in the market. Since their new products have no research and development costs, their prices are naturally low, which can seriously damage, sometimes fatally, the innovative companies that do. Some smart bosses realize the potential profit under hundreds of famous IPs. To reduce the cost of building a brand impression, some enterprises just imitate the company's logo or technique from other nations. Because of the unconsciousness of those imitations and the lack of the regulation system, enterprises that become successful with famous IP do not need to afford any responsibility to their illegal actions. After a long period, with the increasing famous impression of the fake enterprise, the original IP's company will realize the situation of their IP are copied by others and used for their profit without the original company's share.

Suppose this type of issue still happened during the China-EU comprehensive agreement. In that case, the companies whose IP are imitated do not think the current trading atmosphere is fair to both sides, and in their eyes, that is a kind of giving in charity. Considering Mcdonald's again, some companies from other nations utilize the wonderful impression of the Mcdonald's logo and just make a few changes to attract local customers with the shock of the similar logo to Mcdonald's. Local enterprises need to face overseas issues about logos, but they also meet many situations that their techniques are imitated, and some overseas companies gain profit with it. The purpose of the ChinaEU comprehensive investment agreement is to build a fair and beneficial trading atmosphere for both sides, but if there are lots of damage just on the aspect of intellectual property, what about other parts? To solve these problems, making new regulations about IP and undergoing them is one way to efficiently ensure the China-EU comprehensive agreement.

The reasons for making new regulations about IP prevent overseas competitors from copying and preventing the loss of technical achievements. Also, companies do not apply for patents to sell technology but to obtain a monopoly on the patent. Firstly, a new regulation for two areas can efficiently ensure that no more traders will copy other company's intellectual property. The punishment in new regulations will warn those businessmen who want to get profit under the imitation of famous IP. As a result, multinational enterprises do not need to worry about IP problems, and overseas trading can be maintained for a long period.

Secondly, some companies are special because they just sell their techniques, and if the IP problem cannot be solved, their market share will be affected, and their 
profit will disappear a lot. Some new regulations about the protection of intellectual property rights are significant to those types of companies. With the development of the new regulations, those companies are willing to sell the techniques overseas and support the domestic economic development and enhance the technology level of China or Europe. Finally, these new regulations can be the first sample of global trading and leading to more multinational trading around the whole world. China and Europe's economies will be paid more attention. Therefore, the trading between these two areas can be ensured and sustainable.

However, the problem of making new regulations is visible. If new regulations are not fair to both sides, one of them will see the China-EU comprehensive agreement regarding giving in charity to another side rather than a win-win strategy. Therefore, the correction of new international laws between China and Europe must be negotiated several times. The content needs to be checked as practical and efficient in real multinational trading. Implementing new regulations in the China-EU comprehensive agreement is not smooth because multinational enterprises have not met some problems at the beginning of the process of collaboration. In addition, many local companies become angry with multinational enterprises because there are more companies to take the domestic market share or imitate their intellectual property for profits.

On the other hand, these problems can be solved as the practice of China-EU comprehensive agreement, and the IP problem can be solved better and better with the new regulations about this aspect. Not only for solving intellectual problems, making new regulations about IP is a benefit for sustainable development. China-EU comprehensive agreement is the first agreement between various nations for building a fair and profitable atmosphere. Every famous IP's influence is enormous for the whole world, so with the China-EU comprehensive agreement, overseas trading can be done smoothly and ensure overseas profit [6]. With the future possibilities, both China and Europe can be benefited. For example, gaining the techniques from overseas, lower cost on investment in other nations, and ensuring the local company's market share. The successful process between China and Europe can provide a great example for the whole world's trading environment and stimulate the development of the global economy.

\section{CONTENT ON SUSTAINABLE DEVELOPMENT}

Sustainable development is a hot topic in recent years, which highlights the core requirements of modern development. The principle of sustainability balances the interests of the present generation against those of future generations. The literal concept is that the development meets the need of the presentation without endangering future generations to meet their own needs. What is sustainability? Different treaties contain slightly different definitions:

The Brundtland Report provided data on sustainability crises, recommended Goals for a sustainable future, which about "development that meets the needs of the present without compromising the ability of future generations to meet their own needs". The Convention on the Protection and Use of Transboundary Watercourses and International Lakes (1992) say that "Water resources shall be managed so that the needs of the present generation are met without compromising the ability of future generations to meet their own needs." Rio Declaration on Environment and Development regulated that "The right to development must be fulfilled to equitably meet developmental and environmental needs of present and future generations." UN Framework Convention on Climate Change which concluded in 1994, and ratified by 197 countries, "The Parties should protect the climate system for the benefit of present and future generations of humankind, based on equity and in accordance with their common but differentiated responsibilities and respective capabilities."

There are three basic principles about sustainable development. The first is equality. Development is an eternal and urgent requirement that all generations of human beings pursue. China-EU Comprehensive Investment Agreement also implies that people from different religions have equal access to natural resources and social wealth. While, in the international corporation, since sustainable development is a global issue, it's neither the responsibility nor the benefits of a few countries. In the bilateral cooperation, both sides should take relatively equal responsibility, giving up selfish thoughts such as gaining benefits with less cost, even benefiting at the expense of other countries interests. With those selfish thoughts, the international corporation will be blocked out. What's more, this kind of temporary development will cost more to fix. The second is sustainability, which refers to the ability of an ecosystem to maintain its productivity when it's disturbed in some ways. When it comes to the treaty itself, we can assume that it provides the environment with a kind of insurance to face uncertain challenges. Because the resources and environment are the basis and conditions for human survival and development, building environmental resource barriers is necessary. The third is about commonality. It's essential to work towards international agreements that respect the interests of all while protecting the global environment and developing a system-setting balance between present and future generations.

Compared with the previous understanding of 
sustainable development, the UN SDG comes up with a wide, comprehensive description of sustainable development. In my opinion, I consider that the relevant content on labor cares more about human rights. Four major human rights influence the development of trade largely, such as the right to health, labor rights, environmental right, and right of development. In international trade organizations, any settlement of trade disputes factors human rights. But when it's taken into practice, sometimes the human rights fall victim to influence, even being manipulated. Once the human rights-based trade barriers have been set up, trade efficiency will be reduced to a large extend. As a result, to improve the labor standard, we should focus on the fundamental causes of those issues, sorting out the inherent relationship between human rights and free trade. This was compared with what was mentioned on the EU WTO Reform Program, which also showed similar content about labor standards and sustainable development. There is also a clear need to address the discriminatory border practices by reinforcing national treatment obligations and developing strong domestic regulation disciplines ensuring non-discriminatory and transparent regulatory and enforcement processes in the services and non-services sectors. After a period of global development, the gap between the developing and developed countries has been closed up. As a result, they can reach a consensus to some degree on human rights. Take the treatment of works, for example. The general wage gap between Chinese and European workforces in recent years has narrowed. Factory workers in China are earning more than ever as average hourly wages have gone up a significant $64 \%$ since 2011. The trend is expected to continue as salaries for both blue, and white-collar workers are expected to grow by $7 \%$ this year alone. Wage increases are beneficial for Chinese workers as they rise to the level of various European countries. Median wages in Shanghai $(\$ 1,135)$ are now comparable to Hungary $(\$ 1,139)$, Prague $(\$ 1,400)$ and Poland $(\$ 1,569)$. From the precedent treaties, although there is also content related to the protection of human rights, however, since the degree of development is different, they pursue a different degree of protection on human rights. Therefore, they can't provide equivalent labor protection.

Usually, the EU is used to put forward stricter standards on intellectual property rights, environmental protection, labor welfare, human rights, and other aspects. The corresponding requirement includes sustainable development clauses related to labor, environment, and other fields in the BIT negotiations between China and the EU. The EU demands that the host country's capacity for public intervention must be respected in the negotiations, especially in the areas of safeguarding social and environmental standards and human rights, safeguarding labor safety and rights, fighting against counterfeit and shoddy products, safeguarding the public health, and respecting cultural diversity. This reflects the importance that the EU attaches to national public interests. China as a developing country, in terms of sustainable development and legal norms, etc. The European Union and other developed countries are different. It mainly depends on the domestic-related legal norms started late, lack of experience, and social development level still not enough, lead to a domestic social environment lacking in the areas of law, the not mature and a sound management system. At present, China mostly uses consultation to resolve disputes on sustainable development [7]. Therefore, to cope with central European Union square BIT negotiations for sustainable development can be terms appeal. On the one hand, efforts should be made to adapt to the rigid constraint on sustainable development issues, the domestic law to make a certain adjustment, strictly regulate China enterprise overseas investment, promote the standardization of the relevant laws and regulations, and the international standard. On the other hand, we should also identify the requirements of the EU, accurately identify the social barriers and reasonable requirements, and firmly safeguard the interests of China in case of barriers. At the same time, we should improve the level of social standards such as environmental protection and labor protection and strictly control the entry of foreign investment from the EU. This is also a gradual process, and many supporting policies should come along.

One of the most concerning issues is market access, which also cares more about equality and commonality. The market access issue in the BIT negotiation between China and the EU is, in the final analysis, the management model of "pre-establishment national treatment plus negative list", which is the core of the issue of investment liberalization. Pre-establishment national treatment means that the host country gives the foreign investors and investment behaviors the treatment that is not lower than that of the domestic investors and investment behaviors in the investment access stage. A negative list is an exception to preestablishment national treatment, a "blacklist" of investment sectors, which lists sectors and sectors that the destination country is not open to, as opposed to a positive list [8].

The formulation of the negative list must follow three principles, the principle of promoting reform through opening up, the principle of reciprocity opening up, and the principle of earnestly guaranteeing the bottom line of national security. First, the length of the negative list reflects how open the market is. High-level opening-up requires high-standard reform, and only a short negative list can reflect the idea of high-standard reform. China should adhere to the principle of further shortening the negative list and should open to the outside world and the inclusion of restrictive and 
prohibitive measures on the negative list. Second, it should be further emphasized that openness is mutual. The exchange of the negative list should respect the major concerns of the two sides, and the differences on the negative list should be gradually resolved through consultation and negotiation to open their markets to each other. Full consideration should be given to the transformation of China's dual status in international investment. China is both the mother country and the host country of investment. China opens its market to investors from the EU, and at the same time, Chinese investors who invest in the EU should have smooth access to the other side's market and enjoy the fair treatment. In particular, when it comes to SOEs' foreign investment, China should ask the EU side to abandon its bias and make China's SOEs enjoy the same fair treatment as other countries' enterprises in the EU market. It is very important to balance interests. Finally, the bottom line of national security should be upheld. The industries related to the field of national security, such as the basic industries related to economic security, the infrastructure related to public order, the financial field related to macro stability. And the administrative, regulatory measures that need to be retained, should be resolutely prohibited from opening and guaranteed. For the national industries in the initial stage, we should properly include the negative list, take step by step and gradually open measures, give them enough adaptation and transition period, and cultivate their competitiveness. At the same time, China should actively strive for the differential treatment that it should enjoy as a developing country for similar domestic industries that are seriously unequal with the EU in terms of experience and technology, instead of blindly following the pace of the EU in opening up too early. To reach the requirements about sustainable development, countries in the BIT should respect each other, fully consider the differences between each other.

\section{A BRIEF FORECAST OF THE FUTURE OF CHINA-EU COOPERATION, BRIEFLY EXPLAINING BOTH THE OPPORTUNITIES AND THE CHALLENGES}

From the worldwide perspective, the China EU comprehensive agreement is good for the whole world. When the global economy meets some troubles and tends to reverse, the appearance of cooperation of two of the world's most stable power and two main economies in the world can positively affect the other economies in the whole world. In addition, this action will boost world economic recovery in the postepidemic era, enhance international confidence in economic globalization and free trade, and contribute significantly to building an open world economy as the two major markets of China and Europe. As a result, the
China EU investment agreement will inject more certainty and growth momentum into the world economy.

First of all, the agreement will improve China's market access conditions for the development of China, making China's economy more open and attracting more investment [9]. Also, it will attract more foreign investment and other resources from Europe and promote the construction of a powerful trading country. Secondly, China's investment in Europe will be protected, and the investment environment and regulatory procedures will be cleaner and transparent. Therefore, it can be speculated that more Chinese enterprises will have the confidence to carry out business and set up branches in Europe. Thirdly, China can more easily introduce advanced technology and scientific and technological talents from Europe, improve the quality of economic development, and accelerate the development of the modern industrial system.

Although the EU has already gained a competitive edge in high-level technology for the development of Europe, it is hampered by its lack of lasting energy to support economic growth and the hollowing out of the overseas market. Market access has always been at the heart of EU-China investment treaty negotiations for years. The EU mainly seeks financial services, telecommunications, information, and communication technology. They also wish to enjoy a more transparent competitive environment among key factors such as manufacturing, engineering, and biotechnology. Under this agreement, EU investors will achieve better access to a fast-growing 1.4 billion consumer market and compete on a better level playing field in China [10]. The removal of quantitative restrictions, equity caps, or joint venture requirements in some sectors has once severely obstructed the activities of EU companies in China. What's more, some other items such as elimination of quantitative restriction, equity caps, or joint venture requirements in a large number of sectors also pave the way for the EU to enter into the Chinese market.

\section{CONCLUSION}

Overall, for some reasons, we suppose the signing of the agreement will be a win-win situation for China and the European Union, and the cooperation between the two large economies will have an important impact on the world. For Europe, cooperation with China will inject momentum into economic development and help return to the economic level before the epidemic and even before the European debt crisis. For China,similarly, the development of foreign trade can promote economic development. In addition, economy and politics are closely linked, and economic growth can drive political changes. Both China and the EU will 
be promoted in terms of international status and influence. This will also greatly affect the world pattern.

\section{REFERENCES}

[1] Ronald C. Brown, China-EU BIT and FTA: Building a Bridge on the Silk Road Not China-EU BIT and FTA: Building a Bridge on the Silk Road Not Detoured by Labor Standard Provisions, in: Washington International Law Journal Washington International Law Journal, vol. 29, 2019, pp. 62115. DOI: https://digitalcommons.law.uw.edu/wilj

[2] Xinwei Liu, Specification and verification of concurrent systems in CESAR, in: M. DezaniCiancaglini and U. Montanari (Eds.), China's Foreign Trade, 2021, pp. 31-32. DOI: https://kns.cnki.net/kcms/detail/detail.aspx?FileNa me $=$ ZKWM202103011\&DbName=CJFQTEMP

[3] Fang Song, EU's Hard Choice Between China and the United StatesAn Analysis Based on the Perspective of "Cakeism":, Global Review, Beijing, 2021, pp. 7695+155-156. DOI:

https://kns.cnki.net/kcms/detail/detail.aspx?FileNa $\mathrm{me}=\mathrm{GJZW} 202103005 \& \mathrm{DbName}=\mathrm{CJFQTEMP}$

[4] Jian Zhang, EU Strategic Autonomy and China-EU Relations in the

Post-pandemic Era, in:

Contemporary World, Beijing, 2021, pp. 18-23. DOI:

https://kns.cnki.net/kcms/detail/detail.aspx?FileNa $\mathrm{me}=\mathrm{JSDD} 202104004 \& \mathrm{DbName}=\mathrm{CJFQ} 2021$

[5] Jiang Qingyun. Current Situation, Problems and Countermeasures of China-Europe Bilateral Investment Treaty Negotiation [J]. German Research,2014,29(04):81-93+127.

[6] Qin Xiaojing. The Institutional Design of the Investment Court Mechanism to Defend the Legal Autonomy of the European Union and China's Countermeasures $[\mathrm{J}]$. Journal of Law, 201,42(01):111-120.

[7] Jiang Qingyun. Current Situation, Problems and Countermeasures of China-Europe Bilateral Investment Treaty Negotiation [J]. German Research,2014,29(04):81-93+127.

[8] Tang Jie. Recovery and Hope: China and Europe Investment Agreement Negotiation Complets High Level Participation in Global Industry Chain and Value Chain Division [J]. Import and Export Manager,2021(02):48-51.

[9] Yilin Wang, Yun Wang, The impact of "pre- establishment national treatment + negative list" on China-Europe Comprehensive Investment Agreement [J].SocialScience Review,2020,35(12):109-114.

[10] Wei Wei, Zhang Xinxin, Zhao Li. The origin, significance and future prospect of China-Europe investment treaty $[\mathrm{J}]$. Boundary and Marine Studies, 201,6(01):100-115. 